\title{
Vibration injuries in Norwegian forest workers
}

\author{
B. HELLSTR $\emptyset M^{1}$ and $K$. LANGE ANDERSEN \\ The International Biological Programme, Human Adaptability Section, Oslo, Norway
}

\begin{abstract}
Hellstrøm, B., and Lange Andersen, K. (1972). Brit. J. industr. Med., 29, 255-263. Vibration injuries in Norwegian forest workers. A free medical examination with compensation for lost earnings was offered to the forest workers in three areas of eastern Norway. Sixty-six per cent attended (413 workers, of whom 296 used chain saws). The prevalence of Raynaud's phenomenon (RP) was $47 \%$ in chain saw operators, $14 \%$ in forest workers not exposed to vibration, and $9 \%$ in 302 indoor workers not exposed to vibration. The high prevalence of RP in chain saw operators was attributed to a traumatic vasospastic disease (TVD). The average time of latency was eight years. The standard symptoms of TVD were attacks of blanching and numbness. Cyanosis and pain occurred rarely. In subsamples, measurements of tactile two-point discrimination and maximal isometric muscle strength (hand grip and finger pressure) as well as $x$-ray examinations of the wrists and the hands gave no evidence of vibration injury to peripheral nerves, muscles, bones, or joints.
\end{abstract}

The injury threshold for local vibration is poorly defined (Sterner et al., 1950; Axelsson, 1967), and new, potentially harmful vibratory tools are still being marketed. One relatively recent offender in this field is the piston-engine operated chain saw used in forestry. The prevalence and clinical picture of vibration injuries caused by chain saws have differed considerably in various studies (Grounds, 1964; Treiberg, Utbult, Lund, and Plevin, 1964; Kylin and Lidström, 1968; Takagi, 1968; Barnes, Longley, Smith, and Allen, 1969; Taylor, Pearson, Kell, and Keighley, 1971). The present paper reports the prevalence and symptoms of vibratory injuries in Norwegian chain saw operators.

\section{Methods \\ Sampling \\ Our study was part of a general health survey of forest workers carried out by field studies in three areas in eastern Norway (Romedal in 1963; Hurdal in 1968-69; Hernes in 1969-70). The forest workers of seven em- ployers-practically the whole forest worker population \\ ${ }^{1}$ Correspondence: B. Hellstrøm, M.D., IBP-HA, P.O. Box 6094-Etterstad, Oslo 6, Norway.}

in the areas-were offered a free medical examination plus compensation for lost earnings. Sixty-six per cent attended. A later attempt to study the remnant had to be given up.

To estimate the prevalence of Raynaud's phenomenon (RP) in an indoor working population not exposed to occupational vibration, all male participants of a routine periodic health examination appearing before one of us (B.H.) during a certain period of time in 1967 were studied. This group did not differ significantly from the forest workers as far as age was concerned (mean $43.9 \pm$ 11.8 years (S.D.) v. $45.6 \pm 12.3$ years in the forest workers, $0.05<P<0.1$ ), but did so differ in other respects (urban $v$. rural, lower level of daily activity, different nutritional habits). The first 207 subjects studied at Hernes were chosen for studies of non-circulatory vibration injuries. A various number of tests failed, as specified below, and two-point discrimination results obtained in Hurdal (vide infra) were added to the material.

\section{Clinical examination}

A standard medical examination including detailed case histories on vibration exposure and RP was made in every subject. With increasing experience, changing focus of interest-but also varying capacity of the examining teams-the questionnaire was changed several times in the course of the study. 
Tactile two-point discrimination Blunt plastic rods with fixed distances of $0,1.5,3.0,4.5$, and $6.0 \mathrm{~mm}$ were pressed firmly and evenly against the midline of the right and left ring finger pads. The subject, eyes closed, was instructed to report whether he could perceive the gap or not. About 10 answers were obtained on each side of the approximate two-point threshold. The two-point limen was finally estimated by linear interpolation. The standard error of a single determination was $\pm 0.5 \mathrm{~mm}$ (estimated by comparing the bilateral measurements in 49 forest workers without occupational vibratory exposure or RP).

Muscle strength The maximal isometric strength of the hand grip and of finger flexion in the metacarpophalangeal joints was measured bilaterally by straingauge dynamometry. The position of the arm, hand, and the fingers was strictly standardized.

X-ray study X-rays were taken of the hands and wrists. The total $(\mathrm{T})$ and medullary (M) width were measured at the midpoint of both middle metacarpals and the 'osteoporosis index' (cortical area $\left(0.785\left(\mathrm{~T}^{2}-\mathrm{M}^{2}\right)\right.$ as per cent of total area $\left(0 \cdot 785 \cdot \mathrm{T}^{2}\right)$ ) was calculated (Nordin, 1969).

Statistics Only current statistical methods (Snedecor, 1956) were used. Differences in prevalence were tested by chi-square (fourfold table), and differences between means of continuously variable parameters were evaluated by Student's $t$-test. The probabilities for fulfilment of the null hypothesis are given in the text.

\section{Results}

\section{Prevalence of Raynaud's phenomenon}

Raynaud's phenomenon was markedly more frequent in chain saw operators than in workers not exposed to occupational vibration (Table 1). In 15 chain saw users RP was attributed to a single episode of trauma, 'hereditary cold fingers' (Hunt, 1936), or previous use of pneumatic drills, in the remainder to
TABLE 1

Prevalence of Raynaud's Phenomenon

\begin{tabular}{|c|c|c|}
\hline Group & $N$ & Prevalence \\
\hline 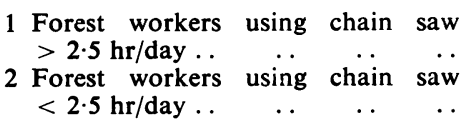 & $\begin{array}{r}212 \\
84\end{array}$ & $\begin{array}{l}55 \\
21\end{array}$ \\
\hline $3=1+2$ Chain saw operators & 296 & 47 \\
\hline 4 Forest workers not using chain saw. . & 117 & 14 \\
\hline 5 Indoor workers & 302 & 9 \\
\hline
\end{tabular}

Significant group differences $(P<0.001): 1 v .2,3 v .4,3 v .5$ Not significant group difference $(P>0 \cdot 1): 4$ v. 5

a 'traumatic vasospastic disease' (TVD) (Wright, 1940) caused by chain saw vibrations. The prevalence of RP appeared to increase with increasing average daily use of the chain saw (Table 1).

Neither age (Table 2) nor smoking (Table 3) appeared to influence the prevalence of RP consistently.

\section{Latent interval of TVD}

Ninety-five subjects with TVD attributable to chain saw vibration were able to recall when they started to use chain saws and when their Raynaud symptoms first started. Based on this information, the time of latency varied from 1 to 18 years (mean 8, S.D. \pm 3.9 years). One hundred and fifty-three fellers who had never experienced RP had used chain saws for from 1 to 22 years (mean and median 9 years). The remaining workers were unable to remember when they started to use chain saws.

TABLE 2

Prevalence of Raynaud's Phenomenon (RP) in Relation to Age

\begin{tabular}{|c|c|c|c|c|c|c|c|c|c|c|}
\hline \multirow{3}{*}{$\begin{array}{l}\text { Age group } \\
(y r)\end{array}$} & & \multicolumn{3}{|c|}{ 1. Chain saw operators } & \multicolumn{3}{|c|}{$\begin{array}{l}\text { 2. Forest workers not using chain } \\
\text { saw }\end{array}$} & \multicolumn{3}{|c|}{ 3. Indoor workers } \\
\hline & & \multirow{2}{*}{$\mathbf{N}$} & \multicolumn{2}{|c|}{ With $R P$} & \multirow{2}{*}{$\mathbf{N}$} & \multicolumn{2}{|c|}{ With $R P$} & \multirow{2}{*}{$\mathbf{N}$} & \multicolumn{2}{|c|}{ With $R P$} \\
\hline & & & no. & $\%$ & & no. & $\%$ & & no. & $\%$ \\
\hline $\begin{array}{ll}20-29^{1} & \ldots \\
30-39 & \ldots \\
40-49 & \ldots \\
50-59 & \ldots \\
60-69^{2} & \ldots\end{array}$ & $\begin{array}{l}\ldots \\
\ldots \\
\ldots \\
\ldots\end{array}$ & $\begin{array}{l}40 \\
62 \\
81 \\
76 \\
37\end{array}$ & $\begin{array}{r}9 \\
29 \\
47 \\
41 \\
12\end{array}$ & $\begin{array}{l}23^{3} \\
47 \\
58^{3} \\
54 \\
32^{3}\end{array}$ & $\begin{array}{l}12 \\
11 \\
30 \\
46 \\
18\end{array}$ & $\begin{array}{l}1 \\
0 \\
3 \\
6 \\
6\end{array}$ & $\begin{array}{c}8 \\
0 \\
10 \\
13 \\
33^{3}\end{array}$ & $\begin{array}{l}44 \\
71 \\
87 \\
63 \\
37\end{array}$ & $\begin{array}{l}6 \\
3 \\
4 \\
8 \\
6\end{array}$ & $\begin{array}{r}14 \\
4 \\
5 \\
13 \\
16\end{array}$ \\
\hline
\end{tabular}

${ }^{1}$ Includes one younger man in group 3, and two in groups 1 and 2.

2Includes two 70-year-old men in group 3.

${ }^{3}$ Prevalences which differed significantly $(P<0.01)$ from that of the remainder of each occupational group ((3) $\left.P<0.02\right)$

The rest of the age group prevalences did not differ significantly from that of the remainder of each occupational group. 
TABLE 3

Prevalence of Raynaud's Phenomenon (RP) in Smokers $v$. Non-Smokers

\begin{tabular}{|c|c|c|c|c|c|c|}
\hline \multirow{2}{*}{\multicolumn{2}{|c|}{ Group }} & \multirow{2}{*}{$N$} & \multirow{2}{*}{$\begin{array}{c}\text { Smokers } \\
(\%)\end{array}$} & \multicolumn{2}{|c|}{ Prevalence of $R P(\%)$} & \multirow{2}{*}{$\begin{array}{c}\text { Significance } \\
\mathrm{a}-\mathrm{b}\end{array}$} \\
\hline & & & & $\begin{array}{c}\text { Smokers } \\
\mathrm{a}\end{array}$ & $\begin{array}{c}\text { Non-smokers } \\
\mathbf{b}\end{array}$ & \\
\hline $\begin{array}{l}\text { Chain saw operators } \\
\text { Forest workers not using chain saws } \\
\text { Indoor workers } \quad .\end{array}$ & $\begin{array}{l}\cdots \\
\cdots \\
\cdots\end{array}$ & $\begin{array}{l}296 \\
117 \\
302\end{array}$ & $\begin{array}{l}69 \\
64 \\
32\end{array}$ & $\begin{array}{r}49 \\
19 \\
9\end{array}$ & $\begin{array}{r}42 \\
5 \\
9\end{array}$ & $\begin{array}{c}P>0.1 \\
0.02<P<0.05 \\
P>0.9\end{array}$ \\
\hline
\end{tabular}

Extent of RP in subjects with TVD possibly due to chain saw vibration

In most subjects the extent of finger blanching reportedly varied somewhat from attack to attack. Emphasis was laid upon the maximum extent of blanching, and a digit was regarded as affected even when only its tip would blanch. Of the 123 workers whose RP was attributable to the use of chain saws, $18(15 \%)$ had all digits affected. Fifty-seven per cent of the right-hand and $42 \%$ of the left-hand digits were affected $(P>0 \cdot 1)$. In 55 subjects, the symptoms occurred symmetrically. The middle and ring fingers were most frequently affected, the thumb most often spared from symptoms (Fig. 1).

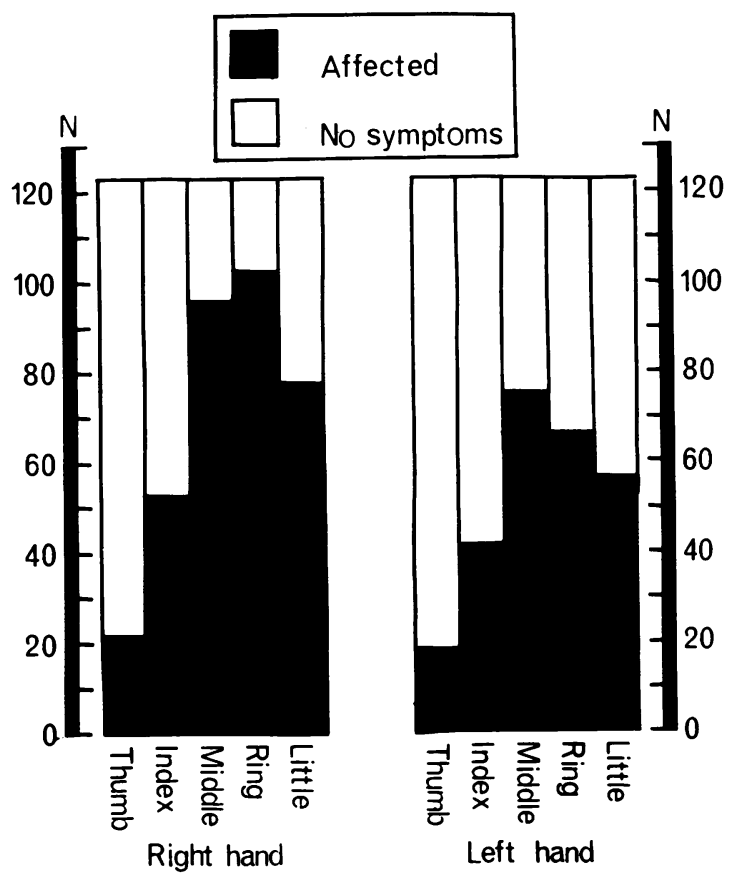

FIG. 1. Localization of Raynaud's phenomenon in 123 chain saw operators with traumatic vasospastic disease.

\section{Symptoms of TVD}

The attacks were produced by cold, particularly 'wet cold', and hardly ever by vibration alone. The combined effect of a sustained hand grip, vibration, and cold produced by driving a motorcycle or a car in cold damp weather was the surest trigger in many cases. Attacks were most frequent in the morning and in the afternoon, and rarely occurred when the subjects had worked themselves warm. No subject had ever experienced nocturnal attacks or emotional triggering.

During the attack, blanching and numbness were the usual symptoms. During rewarming, 'pins and needles' were the regular complaints (Table 4). Between attacks, 84 out of $94(89 \%)$ subjects with TVD had no symptoms, and the remainder were rather vague on the following local disturbances: weakness of hand grip, stiffness of the fingers, and clumsiness. Neither pain nor impaired sensation between attacks was reported by any subject.

TABLE 4

SyMPTOMS OF OCCUPATIONAL RaYNAUD'S

Phenomenon in Chain Saw Operators

(Per cent of subjects in each group reporting symptoms as stated)

\begin{tabular}{|c|c|c|c|c|}
\hline \multicolumn{2}{|c|}{$\begin{array}{l}\text { Attacks per year } \\
(\mathrm{N}=123)\end{array}$} & \multicolumn{3}{|c|}{$\begin{array}{l}\text { Symptoms during attacks } \\
(\mathrm{N}=123)\end{array}$} \\
\hline $\begin{array}{r}>100 \\
10-100 \\
<\quad 10\end{array}$ & $\begin{array}{l}22 \\
54 \\
24\end{array}$ & $\begin{array}{ll}\text { Numbness } & \ldots \\
\text { Blanching } & \ldots \\
\text { Stiffness } & \ldots\end{array}$ & $\begin{array}{l}\cdots \\
\cdots \\
\cdots\end{array}$ & $\begin{array}{r}100 \\
96 \\
41\end{array}$ \\
\hline \multicolumn{2}{|c|}{$\begin{array}{l}\text { Recovery time (min) } \\
\quad(\mathrm{N}=78)\end{array}$} & \multirow{2}{*}{\multicolumn{2}{|c|}{$\begin{array}{lcl}\text { 'Pins and needles' } & \ldots \\
\text { Pain } \ldots & . . & \ldots \\
\text { Cyanosis } & . & .\end{array}$}} & $\begin{array}{r}11 \\
9\end{array}$ \\
\hline \multirow[t]{3}{*}{$\begin{array}{rr}< & 5 \\
< & 15 \\
\therefore \quad & 60\end{array}$} & $\begin{array}{r}41 \\
81 \\
1\end{array}$ & & & \\
\hline & & \multicolumn{3}{|c|}{$\begin{array}{l}\text { Symptoms during rewarming } \\
(\mathrm{N}=78)\end{array}$} \\
\hline & & $\begin{array}{l}\text { 'Pins and needles' } \\
\text { Pain .. } \\
\text { Cyanosis } \\
\text { None .. } \\
\text {.. }\end{array}$ & $\begin{array}{l}\cdots \\
\cdots \\
\cdots \\
\cdots\end{array}$ & $\begin{array}{r}90 \\
22 \\
4 \\
10\end{array}$ \\
\hline
\end{tabular}


Physical signs in subjects with Raynaud's phenomenon Neither trophic lesions nor cyanosis were observed during the clinical examination which took place at ordinary room temperature.

\section{Tactile discrimination}

Two-point thresholds were not obtained in two subjects who did not cooperate properly, and were also impossible to determine in four fingers due to local lesions. The data from an earlier study by a comparable method (the V-test of Mackworth, 1953) in 26 of the Hurdal chain saw operators with RP (Hellstrøm, Stensvold, Halvorsrud, and Vik, 1970) were included.

The two-point threshold did not differ significantly between users and non-users of chain saws (Table 5). The threshold was slightly but significantly $(P<$ 0.01) higher in subjects with than without RP. However, in 37 workers with unilateral ring finger affection, the two-point threshold was on the average only $0.1 \mathrm{~mm}$ larger on the affected side (P > 0.5).

Among the subjects with the highest two-point threshold, no worker was found with exceptionally high values attributable to vibratory peripheral nerve injury.

\section{Muscle strength}

Results were not obtained in seven workers because of technical trouble.

Operators of chain saws tended to have a weaker hand grip than workers not exposed to occupational vibration, as did subjects with $R P$ when compared
TABLE 5

Tactile Two-point Threshold on Pads of Ring FINGERS IN 231 FOREST WORKERS

\begin{tabular}{lll|c|c}
\hline \multicolumn{1}{c|}{ Group } & & $N^{1}$ & $\begin{array}{c}\text { Threshold }(\text { mm }) \\
\text { (mean } \pm \text { SEM) }\end{array}$ \\
\hline Using chain saws &. & $\ldots$ & 352 & $3.5 \pm 0.04$ \\
Not using chain saws &. &. & 106 & $3.6 \pm 0.07$ \\
Raynaud phenomenon &. & 197 & $3.6 \pm 0.06$ \\
No Raynaud phenomenon &. & 261 & $3.4 \pm 0.05$ \\
\hline
\end{tabular}

${ }^{1}$ Number of 4 th fingers tested. Data obtained in only one finger in four subjects.

with those free from such symptoms (Fig. 2). A similar trend was present in finger pressures (data not shown), but for all parameters the group differences fell short of statistical significance.

\section{Lesions of bones and joints}

From slight to marked periosteal appositions, as described by Humperdinck (1940) and probably a consequence of heavy manual labour (McLaren, 1937), were found in the fingers of most subjects whether they used chain saws or not. Minor cyst-like areas of decalcification and osteoarthritic changes were also fairly common but apparently unrelated to the use of chain saws or the presence of RP (Table 6).

In the $x$-ray pictures of the hands of 23 workers, slight blurring of one or both metacarpals made exact measurements of the osteoporosis index im-

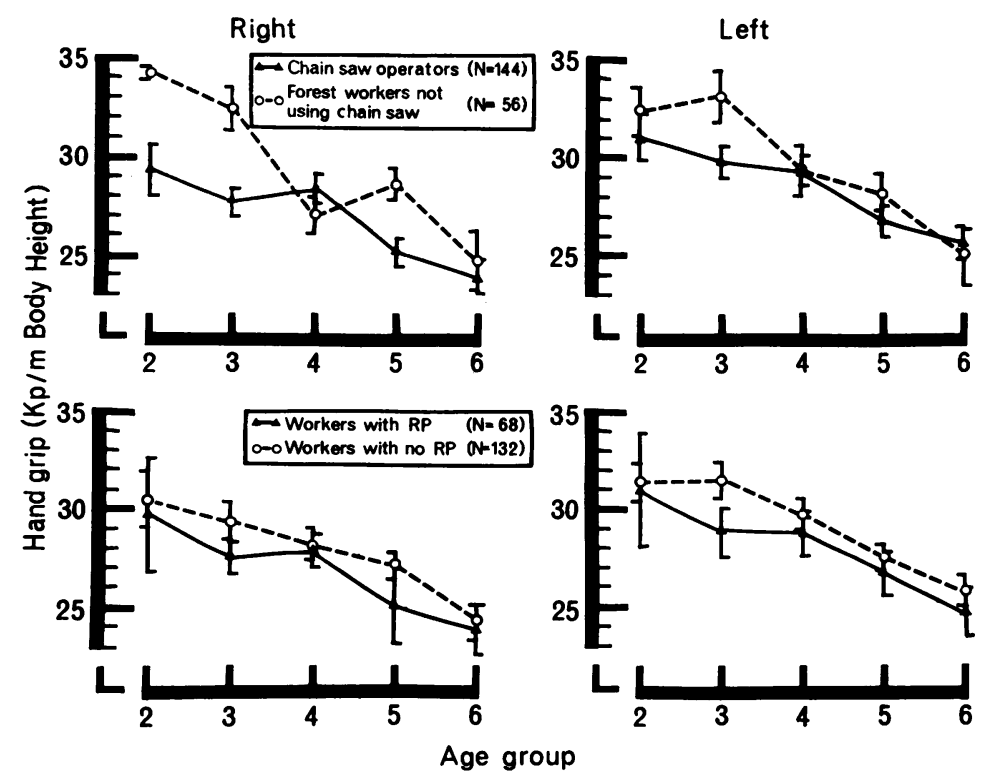

FIG. 2. Hand grip strength related to body height and age. Age group 2: subjects 20-29 years old; age group 3: subjects 30-39 years old, and so on. Vertical bars mark \pm SEM. 


\section{TABLE 6}

LESIONS OF BONES AND JOINTS

(Per cent of 207 forest workers with lesions as specified in right $v$. (left) wrist and hand)

\begin{tabular}{|c|c|c|c|c|}
\hline & $\begin{array}{c}\text { Using } \\
\text { chain saw } \\
(\mathrm{N}=150)\end{array}$ & $\begin{array}{l}\text { Not using } \\
\text { chain saw } \\
(\mathrm{N}=57)\end{array}$ & $\begin{array}{c}\text { Having } \\
\quad R P \\
(\mathrm{~N}=73)\end{array}$ & $\begin{array}{c}\text { Not } \\
\text { having } \\
R P \\
(\mathrm{~N}=134)\end{array}$ \\
\hline $\begin{array}{l}\text { 'Cysts' . } \\
\text { Osteoarthritis .. } \\
\text { Other lesions . . }\end{array}$ & $\begin{array}{l}39(38) \\
26(28) \\
20(18)\end{array}$ & $\begin{array}{l}53(54) \\
32(35) \\
30(21)\end{array}$ & $\begin{array}{l}40(36) \\
32(21) \\
14(15)\end{array}$ & $\begin{array}{l}44(46) \\
25(35) \\
28(21)\end{array}$ \\
\hline
\end{tabular}

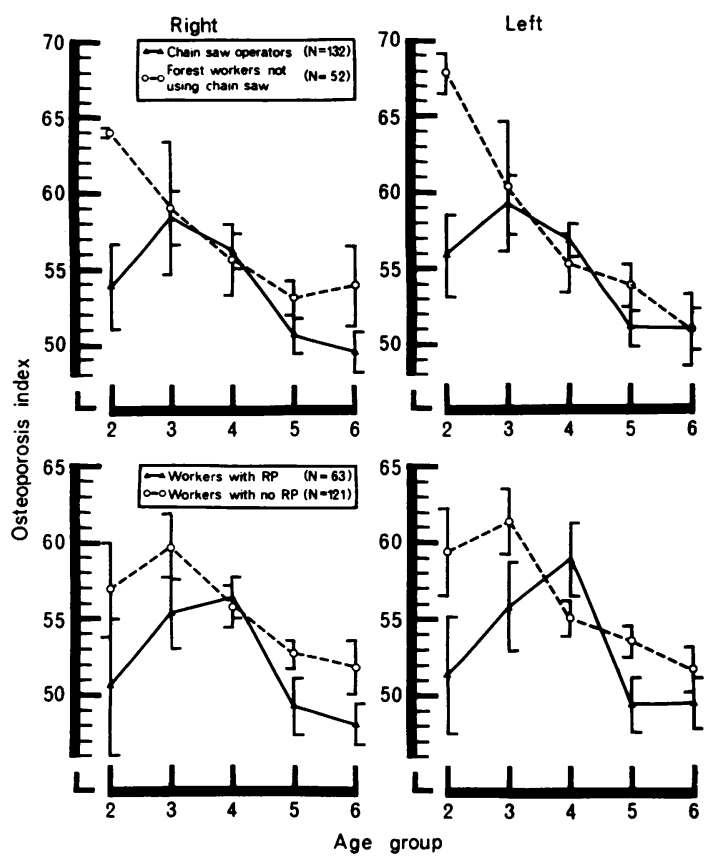

FIG. 3. Nordin's (1969) index of osteoporosis (see text) related to age. Age groups as in Fig. 2. Vertical bars mark \pm SEM.

possible. The results obtained in the remaining 184 subjects indicated that osteoporosis of the metacarpals was not influenced by chain saw vibration, as no statistically significant group difference was found (Fig. 3).

\section{Discussion}

Prevalence of Raynaud's phenomenon in chain saw operators

The regrettably low attendance renders our estimate of prevalence inaccurate but does not invalidate the conclusion that RP was more frequent among chain saw operators than in forest workers who did not use vibratory tools. (Even if every man who did not attend had been a chain saw operator without RP, which was not the case, the $27 \%$ prevalence of RP among chain saw operators would still be significantly higher than the $14 \%$ among the forest workers who did not use chain saws; $c f$. Rose and Blackburn (1968)). We were unable to clarify why so many subjects failed to appear, but the information we got indicated that sheer inconvenience plus a certain general suspicion rather than the presence or absence of Raynaud phenomenon played the major role in this respect. We have no reason to doubt the credibility of the subjects we studied. The low prevalence of symptoms reported between attacks does not indicate any tendency to exaggeration. Also, in 44 of the present subjects with TVD who were re-examined after several weeks, the two histories corresponded closely. Ultimately, in 11 out of 11 workers with alleged TVD, RP was provoked experimentally by a combined general and local cold exposure, whereas no such symptoms appeared in seven controls who denied having RP (Hellstrøm and Myhre, 1971).

Our results confirm that the use of chain saws can produce TVD, as was first reported by Grounds (1964), and run contrary to the statement of Pecora, Udel, and Christman (1960) that RP of occupational origin is disappearing. The present prevalence of RP agrees closely with the $49 \%$ found by Kylin and Lidström (1968) but is markedly lower than the prevalences reported by Grounds (1964) and by Takagi (1968) and the more than $80 \%$ found in several groups exposed to various other types of occupational vibration (Riesenfeld-Hirschberg, 1928; Grotjahn, 1931; Hamilton, 1930; Seyring, 1930; Bruusgaard, 1941; Ponhold, 1943; Hunter, McLaughlin, and Perry, 1945; Agate, Druett, and Tombleson, 1946; Anda, 1960). The reason for this discrepancy may lie in the vibration characteristics of the various tools, in the conditions under which they are used, or in the subjects who use them. Each set of factors offers still unresolved problems.

The chain saw vibrations analysed by Kaminsky (1963) and by Axelsson (1967) were within the zone of hazard proposed by Agate and Druett (1947), as were the vibrations estimated by Grounds (1964). However, the vibrations vary between different models of chain saws, with the type of work done, and with the conditions of the saw (Axelsson, 1967). The present workers had used more than 40 chain saw models in all, and many wore out one saw every year. To obtain even a rough estimate of the vibrations received by the hands of one worker up to the point when he shows TVD is a formidable task, beyond our capabilities. Such information is sorely needed, however, both to evaluate the part played by the factors presumed to be of importance for the 
pathogenesis of TVD and to obtain well-founded safety limits for local vibration.

Various working conditions have been suggested as having an effect on the development of TVD: tight grip (Hamilton, 1930; Marshall, Poole, and Reynard, 1954), overhead drilling (Hunter et al. 1945; Ashe and Williams, 1964), and a cold environment (Hamilton, 1930; Davies, Glaser, and Collins, 1957; Williams and Riegert, 1961). Their effect is possibly twofold: (1) determining the amount of vibratory energy absorbed by the hands, and (2) modifying the condition of the hands (particularly their blood flow) during vibratory exposure. The most obvious reason for the relatively low prevalence of TVD in our subjects is the fact that until recently the chain saws were used for only a few hours a day and usually with long vibration-free pauses between exposures. Intermittent exposure may lower the incidence of TVD (Riesenfeld-Hirschberg, 1928; Pecora et al., 1960; Magos and Okos, 1963). Another factor of possible relevance is the strenuousness of forest work (total daily caloric intake often more than $6000 \mathrm{kcal}$ ), which must provide a strong drive for peripheral vasodilatation even in very cold environments (e.g., Hellstrøm, Berg, and Vogt Lorentzen, 1970).

Our results indicate a wide variation in the individual susceptibility to occupational vibration. Although generally accepted (e.g., Agate, 1949), the basis for this variation in resistance to vibration is poorly known. It may be anatomical (pattern of arm/hand vasculature (Seyring, 1930) or resonance frequency of the hand/arm system (Sroka, 1951; Coermann and Lange, 1967)), physiological (Wright, 1940; de Takats, 1945), or a benefit from particularly skilful use of the tool (Hamilton, 1930). Grotjahn's (1931) observation that young workers were especially vulnerable to local vibration was not confirmed by Agate (1949) nor by the present findings where the prevalence of RP in the youngest group was significantly lower than in the rest of the chain saw operators (Table 2). As in the studies of Telford, McCann, and MacCormack (1945) and Barnes et al. (1969), smoking was of no importance (Table 3).

Forest work in Norway can acclimatize the worker to cold with a consequent improvement of finger blood flow in the cold (Strømme, Lange Andersen, and Elsner, 1963) and reduced cold pain and cold pressor responses (Hellstrøm, 1965). Telford et al. (1945) found that previous outdoor work delayed the onset of TVD. A similar effect of acclimatization to cold in the present subjects is conceivable, but an improved cold tolerance may as well enhance the development of TVD as it leads to abandoning local protection (against vibration as well as cold) even in very cold weather.

We have, at present, neither the means to improve individual resistance against TVD nor the methods to reveal (and exclude from vibration) those subjects with a particularly low resistance against TVD.

Prevalence of Raynaud's phenomenon not caused by vibration

The $14 \%$ prevalence of RP in forest workers not exposed to vibration did not differ significantly from the $9 \%$ in indoor workers (Table 1). These results are in agreement with the $12 \%$ found by Kylin and Lidström (1968) and the 8\% reported by Renard (1963) in comparable groups in Sweden. Raynaud's phenomenon can be caused by a wide variety of diseases (Jepson, 1951), most of which are rare. About $90 \%$ of the present cases with RP of nonoccupational origin had 'hereditary cold fingers' (Hunt, 1936). Lewis and Pickering (1934) estimated the prevalence of this harmless condition at $25 \%$ in young men. The factors determining the prevalence of 'hereditary cold fingers' are unknown.

\section{Latent time of TVD}

The free interval of TVD varies from one week (Marshall et al., 1954) to more than 20 years (Jepson, 1954). The present eight years are an exceptionally long average free interval, however, previously found only in Finnish stone masons using pneumatic drills (Vainio, 1950). Japanese chain saw operators had a mean latent interval of 4.7 years (Takagi, 1968) and Australian forest workers 3.15 years (Grounds, 1964), which are in better keeping with the two to three years most commonly reported (Jones, 1960) than our results. The factors determining the relatively low prevalence of TVD in the present investigation may have contributed to the long time of latency as well.

\section{Symptoms of TVD}

Except for the particular syndrome caused by highspeed vibratory tools (Dart, 1946; Peters, 1946; Agate and Druett, 1947) the clinical picture of TVD has been described as 'almost stereotyped' (Drenckhahn, 1936; Gurdjian and Walker, 1945; Hoerner, 1952) and indeed was so in our subjects. The occurrence of cyanosis and pain varies considerably in various studies (compare, e.g., Hunt (1936), Hunter et al. (1945), Telford et al. (1945), Agate (1949), and Takagi (1968)) and was remarkably low in the present study. Cyanosis is apparently a late feature of TVD (Ashe, Cook, and Old, 1962), related to the severity of the disease (Agate, 1949). Pain was but reluctantly admitted by the present subjects and may have been underestimated. The extent of the lesion (Fig. 1) reflects the fact that both hands are exposed to chain saw vibration. An asymmetrical distribution of RP (Jones, 1960) is of little diagnostic value in these subjects. 
Tactile discrimination

Although several authors have reported intact peripheral sensation in subjects with TVD (Hardgrove and Barker, 1933; Telford et al., 1945; Agate, 1949; Ashe et al., 1962), there is ample evidence that occupational vibration, including that from chain saws (Takagi, 1968), can damage peripheral nerves and impair sensation (Hamilton, 1930; Seyring, 1930; Grotjahn, 1931; Fløystrup, 1948; Jepson, 1954; Ejrup and Sjöström, 1955). TVD has been hypothetically linked to peripheral nerve damage (Cummins, 1940; de Takats, 1945; Marshall et al., 1954), and Anda (1960) even regards sensory impairment a sine qua non for the diagnosis of TVD. Our results do not support this view. The method is crude, but the results agree closely with earlier findings by a more precise approach in forest workers (Hellstrøm, 1965). The threshold is higher than that found in, for example, students (Hellstrøm, 1965), most probably a result of the toughened finger skin in forest workers rather than because of nerve injury. As the chain saw operators had about the same two-point threshold as those not exposed to vibration, our findings fail to substantiate the recent hypothesis (Stewart and Goda, 1970) that occupational vibration causes TVD by toughening the skin.

\section{Muscle strength}

A direct vibratory injury of muscles may occur (Beintker, 1930; Teleky, 1938) but most cases of muscle atrophy attributed to occupational vibration have apparently been secondary to lesions of peripheral nerves (Seyring, 1930; Silberkuhl, 1943; Hunter et al., 1945; Marshall et al., 1954) and a few cases to lesions of the spinal cord (Maassen and Büttner, 1940; Novotný and Uher, 1959). In keeping with their intact peripheral sensation, the present subjects presented no visible atrophy of the hand muscles nor any significant impairment of muscle strength. These negative findings, which agree with those of Hamilton (1930), Grotjahn (1931), Hunt (1936), Agate (1949), and Ashe et al. (1962), contrast sharply with the results of Takagi (1968), possibly because of different vibratory exposures in the two groups.

\section{Lesions of bones and joints}

With the possible exception of small cyst-like areas of decalcification (Brailsford, 1936; McLaren, 1937; Davies et al., 1957) lesions of the bones and joints attributed to occupational vibration are relatively infrequent (Rostock, 1936; Vossenaar, 1936; Teleky, 1938; Siebs, 1941) and hardly pathognomonic of vibratory injury. These cyst-like areas of decalcification have also been attributed to constant jarring of the joints (Hunter et al., 1945). The present $x$-ray findings provide no evidence that the occupational vibration to which our subjects had been exposed had exerted any marked influence on the osteoporotic processes or been the causative agent of the various, quite frequent, but mostly minor pathological lesions in the hands.

\section{Disability}

A high rate of heat production is possibly an excellent prophylactic against attacks of RP during work. Attacks before work started and extra local protection (gloves and mittens) hampered work but not to the extent of jeopardizing wage earning. The relatively benign picture of TVD outlined above is possibly due mainly to a short daily exposure time. In the course of the last few years lopping by chain saw has become common, increasing the average daily exposure time to five to six hours, or more in the most arduous workers. On the other hand, manufacturers now try to reduce chain saw vibrations and have also introduced warmed handles. What impact these opposite trends will have on the prevalence and the clinical picture of vibratory lesions in forest workers is hard to predict, but there is little hope that the widespread, although not very grave, damage already inflicted will disappear (Hunt, 1936; Agate, 1949; Marshall et al., 1954).

J. S. Kaczynski made the $x$-ray measurements and T. Nesse tested the muscle strength. The authors are also indebted to staff members of The Institute of Occupational Health, The Hernes Institute, and The Norwegian Forest Research Institute for their participation in the health survey. Mrs. Kari Hesselberg provided expert technical assistance.

\section{References}

Agate, J. N. (1949). An outbreak of cases of Raynaud's phenomenon of occupational origin. Brit. J. industr. Med., 6, 144-163.

, and Druett, H. A. (1947). A study of portable vibrating tools in relation to the clinical effects which they produce. Brit.J. industr. Med., 4, 141-163.

,-- , and Tombleson, J. B. L. (1946). Raynaud's phenomenon in grinders of small metal castings. Brit. J. industr. Med., 3, 167-174.

Anda, B. (1960). Forekomsten av vasospastiske forstyrrelser ('hvite fingre') blant gruvearbeidere i Sulitjelma. Nord. hyg. T., 41, 123-147.

As'ee, W. F., Cook, W. T., and Old, J. W. (1962). Raynaud's phenomenon of occupational origin. Arch. environm. Hlth, 5, 333-343.

- and Williams, N. (1964). Occupational Raynaud's II. Further studies of this disorder in uranium mine workers. Arch. environm. Hlth, 9, 425-433.

Axelsson, S.-A. (1967). Analysis of Vibrations of Power Saws. Department of Operational Efficiency, Royal College of Forestry. Research Note No. 31. Stockholm.

Barnes, R., Longley, E. O., Smith, A. R. B., and Allen, J. G. (1969). Vibration disease. Med. J. Aust., 1, 901-905.

Beintker (1930). Über Muskelatrophien durch Pressluftwerkzeuge. Arch. Gewerbepath. Gewerbehyg., 1, 376-379.

Brailsford, J. F. (1936). Pathological changes in bones and joints induced by injury. Brit. med. J., 2, 657-663. 
Bruusgaard, A. (1941). Om optreden av angionevrotiske forstyrrelser i hendene ('døde hender') hos bankere i skotøyindustrien. Nord. hyg. T., 22, 309-318.

Coermann, R., and Lange, W. (1967). Einwirkung mechanischer Schwingungen auf das Hand-Arm System. VDIBerichte No. 113, 101-104.

Cummins, R. C. (1940). 'Dead hand': a lesion produced by rapid vibration. Irish $J$. med. Sci., pp. 171-175.

Dart, E. E. (1946). Effects of high speed vibrating tools on operators engaged in the airplane industry. Occup. Med., 1, 515-550.

Davies, T. A. L., Glaser, E. M., and Collins, C. P. (1957). Absence of Raynaud's phenomenon in workers using vibratory tools in a warm climate. Lancet, 1, 1014-1016.

de Takats, G. (1945). Discussion (of paper of Gurdjian and Walker (op. cit.)). J. Amer. med. Ass., 129, 762.

Drenckhahn, C. H. (1936). Vasospastic disease of the hands of miners due to vibration. Illinois med. J., 70, 354-357

Ejrup, B., and Sjöström, B. (1955). Raynauds fenomen hos tillbankningsarbetare. Nord. Med., 53, 985-990.

Flфystrup, A. (1948). Eensidig 'Raynaud-lignende' karlidelse udl $\phi$ st ved nittearbejde med pneumatisk hammer værkt $\phi \mathrm{j}$. Ugeskr. Lag., 110, 957-959.

Grotjahn, M. (1931). Untersuchungen bei Anklopfern in der Schuhindustrie. Arch. Gewerbepath. Gewerbehyg., 1, 687-702.

Grounds, M. D. (1931). Raynaud's phenomenon in users of chain saws. Med. J. Aust., 1, 270-272.

Gurdjian, E. S., and Walker, L. W. (1945). Traumatic vasospastic disease of the hand (white fingers). J. Amer. med. Ass., 129, 668-672.

Hamilton, A. (1930). A vasomotor disturbance in the fingers of stonecutters. Arch. Gewerbepath. Gewerbehyg., 1, 348-358.

Hardgrove, M. A. F., and Barker, N. W. (1933). Pneumatic hammer disease: a vasospastic disturbance of the hands in stone-cutters. Proc. Mayo Clin., 8, 345-349.

Hellstrøm, B. (1965). Local Effects of Acclimatization to Cold in Man. Universitstsforlaget, Oslo.

_-, Berg, K., and Vogt Lorentzen, F. (1970). Human peripheral rewarming during exercise in the cold. J. appl. Physiol., 29, 191-199.

_- , and Myhre, K. (1971). A comparison of some methods of diagnosing Raynaud phenomena of occupational origin. Brit. J. industr. Med., 28, 272-279.

- Stensvold, I., Halvorsrud, J. R., and Vik, T. (1970). Finger blood circulation in forest workers with Raynaud phenomena of occupational origin. Int. Z. angew. Physiol., 29, 18-28.

Hoerner, E. F. (1952). Traumatic vasospastic disease of the hand (Raynaud's phenomenon). Industr. Med. Surg., 21, 297-302.

Humperdinck, K. (1940). Atrophie der kleinen Handmuskeln bei Formern. Folge langjähriger Arbeiten mit Pressluftstampfern? Mschr. Unfallheilk., 47, 71-79.

Hunt, J. H. (1936). Raynaud's phenomenon in workmen using vibrating instruments. Proc. roy. Soc. Med., 30, 171-178.

Hunter, D., McLaughlin, A. I. G., and Perry, K. M. A. (1945). Clinical effects of the use of pneumatic tools. Brit. J. industr. Med., 2, 10-16.

Jepson, R. P. (1951). Raynaud's phenomenon-a review of the clinical problem. Ann. roy. Coll. Surg. Engl., 9, 35-51.

- (1954). Raynaud's phenomenon in workers with vibratory tools. Brit.J. industr. Med., 11, 180-185.

Jones, W. A. (1960). Vibration Injury from Hand Tools-a Critical Review. Thesis, The Ohio State University, Athens, Ohio.

Kaminsky, G. (1963). Zur Frage der Auswirkungen von Lärm und Vibration auf den Waldarbeiter. Der Forst- und Holzwirt, 18, 46-49.

Kylin, B., and Lidström, I.-M. (1968). Undersökning över vibrationsskador hos skogsarbetare. In Hälso- och miljöundersökning bland skogsarbetare, edited by $\mathrm{B}$. Kylin, G. Gerhardson, E.-E. Hansson, I.-M. Lidström, B. Liljenberg, §. Swensson, and I. Åstrand, pp. 44-62. Arbetsmedicinska Institutet, Stockholm.

Lewis, T., and Pickering, G. W. (1934). Observations upon maladies in which the blood supply to digits ceases intermittently or permanently, and upon bilateral gangrene of digits; observations relevant to so-called 'Raynaud's disease'. Clin. Sci., 1, 327-366.

Maassen, R., and Büttner, H. E. (1940). Halsmarkdegeneration mit sekundärer spinaler Muskelatrophie durch Arbeit am Presslufthammer. Arch. Gewerbepath. Gewerbehyg., 10, 19-23.

Mackworth, N. H. (1953). Finger numbness in very cold winds. J. appl. Physiol., 5, 533-543.

Magos, L., and Okos, G. (1963). Raynaud's phenomenon. The situation in the Hungarian iron, steel, and engineering industry. Arch. environm. Hlth, 7, 341-345.

Marshall, J., Poole, E. W., and Reynard, W. A. (1954). Raynaud's phenomenon due to vibrating tools. Neurological observations. Lancet, 1, 1151-1156.

McLaren, J. W. (1937). Disability of workers using pneumatic drills. Lancet, 2, 1296-1299.

Nordin, B. E. C. (1969). Osteoporosis. Proc. VIII Internat. Congr. Gerontology, Vol. 1, pp. 220-224. International Association of Gerontology, Washington D.C.

Novotný, S., and Uher, G. (1959). Beitrag zur spinalen Schädigung durch Pressluftwerkzeugarbeit. Arch. Gewerbepath. Gewerbehyg., 17, 339-346.

Pecora, L. J., Udel, M., and Christman, R. P. (1960). Survey of current status of Raynaud's phenomenon of occupational origin. Amer. industr. Hyg. Ass. J., 21, 80-83.

Peters, F. M. (1946). A disease resulting from the use of pneumatic tools. Occup. Med., 2, 55-66.

Ponhold, J. (1943). Zur Frage der weissen Hände bei den Blechspannern und Schleifern. Arch. Gewerbepath. Gewerbehyg., $12,102-111$.

Renard, K. G. S. T. Clair (1963). Kärlkramp vid borrningsarbete. Medd. Svenska Gruvföreningen, 7 (no. 105).

Riesenfeld-Hirschberg, F. (1928). Über Berufsschädingungen der Anklopfer in der Schuhfabrikation. Zbl. Gewerbehyg., 15 (n.s. 5), 14-16

Rose, G. A., and Blackburn, H. (1968). Cardiovascular Survey Methods. Monograph series No. 56, p. 57. W.H.O., Geneva.

Rostock, P. (1936). Gelenkschäden durch Arbeiten mit Pressluftwerkzeugen und andere schwere körperliche Arbeit. Med. Klin., 32, 341-343.

Seyring, M. (1930). Erkrankungen durch Arbeit mit Pressluftwerkzeugen. Arch. Gewerbepath. Gewerbehyg., 1, 359-375.

Siebs, E. (1941). Die Presslufterkrankungen im Bereiche der Sektion I der Knappschafts-Berufgenossenschaft Bonn, von 1929-1940. Arch. orthop. Unfall-Chir., 41, 137-155.

Silberkuhl, W. (1943). Über Art, Häufigkeit und Entstehung peripherer Nervenerkrankungen bei Pressluftarbeitern. Mschr. Unfallheilk., 50, 120-130.

Snedecor, G. W.(1956). Statistical Methods, 5th ed. Iowa State University Press, Ames, Iowa.

Sroka, K. H. (1951). Zur Frage der Vibrationserkrankungen. Z. Orthop., 80, 487-493.

Sterner, J. H., Barnes, E. C., Brown, E. W., Guillemin, V., Jr., Markuson, K. E., McFarland, R. D., Nelson, N., Ray, W. H., Rose, J., and Tinker, M. (1950). Ninth annual congress on industrial health. Report of the panel on environmental hygiene. Arch. industr. Hyg., 1, 601-614.

Stewart, A. M., and Goda, D. F. (1970). Vibration syndrome. Brit. J. industr. Med., 27, 19-27.

Stromme, S., Lange Andersen, K., and Elsner, R. W. (1963). Metabolic and thermal responses to muscular exertion in the cold. J. appl. Physiol., 18, 756-763. 
Takagi, S. (1968). Raynaud's phenomenon due to chain saw and chipping machine. Jap. Circulat. J., 32, 99-110. (English summary, pp. 32-33).

Taylor, W., Pearson, J., Kell, R. L., and Keighley, G. D. (1971). Vibration syndrome in Forestry Commission chain saw operators. Brit. J. industr. Med., 28, 83-89.

Teleky, L. (1938). Pneumatic tools. In: Occupation and Health; Encyclopedia of Hygiene, Pathology and Social Welfare. Supplement, pp. 1-12. International Labour Office, Geneva.

Telford, E. D., McCann, M. B., and MacCormack, D. H. (1945). 'Dead hand' in users of vibrating tools. Lancet, 2, 359-360.

Treiberg, B., Utbult, B., Lund, F., and Plevin, E. (1964). Effects of Power Saw Vibrations on Forest Workers.
Department of Operational Efficiency, Royal College of Forestry, Res. Note No. 22, Stockholm.

Vainio, K. (1950). Om vibrationssyndrom, särskilt hos maskinborrare. Nord. Hyg. T., 31, 249-267.

Vossenaar, A. H., (1936). Affections articulaires dues au maniement des outils pneumatiques. Écho. méd. Nord. 3rd ser., 6, 949-960.

Williams, N., and Riegert, A. L. (1961). Raynaud's phenomenon of occupational origin in uranium miners. Occup. Hlth Rev., 13, 3-8.

Wright, I. S. (1940). Industrial medicine-and its relation to peripheral vascular disease and injury. Industr. Med. Surg., 9, 460-471.

Received for publication September 2, 1971. 